\title{
Moderating Effects of Firm Size and Leverage on the Working Capital Finance-Profitability Relationship: Evidence from China
}

\author{
Faisal Mahmood ${ }^{1, *}$, Dongping Han ${ }^{1}$, Nazakat Ali ${ }^{2}$, Riaqa Mubeen ${ }^{1}$ and Umeair Shahzad ${ }^{3}$ \\ 1 School of Economy \& Management, Harbin Institute of Technology, Harbin 150001, China; \\ handongping@hit.edu.cn (D.H.); mubeenriaqa@stu.hit.edu.cn (R.M.) \\ 2 School of Management, Iqra University, Islamabad 44000, Pakistan; alinazakat563@gmail.com \\ 3 School of Management, Ocean University, Qingdao 266100, China; mehrzadah009@yandex.com \\ * Correspondence: faisal_mahmood217@hit.edu.cn
}

Received: 25 February 2019; Accepted: 2 April 2019; Published: 5 April 2019

\begin{abstract}
We evaluated the moderating effects of firm size and leverage on the working capital finance (WCF)-profitability relationship among Chinese companies during 2000-2017. Applying the generalized method of moments (GMM) technique on panel data, we observed that firm size and leverage have strong moderating roles in the WCF-profitability relationship. We observed that small or low-leverage firms have an inverted U-shaped WCF-profitability relationship. However, this relationship is U-shaped for large or high-leverage firms. We report break-even points in these relationships that show the portion of short-term debt in working capital financing. The results reveal that the break-even point for all subgroups (small, large, low-leverage, and high-leverage firms) decreases compared to the break-even point of the full sample. This study shows how the break-even point of the WCF-profitability relationship shifts when a company expands or its leverage level changes. Managers can use this information for profit maximization.
\end{abstract}

Keywords: working capital finance; short-term borrowings; profitability; breakeven point; generalized method of moments; firm size; leverage

\section{Introduction}

The relationship between profitability and working capital has remained a critical issue since the late 1990s. The literature defines working capital as the value of current assets after excluding current liabilities [1-3] and refers to the management of current assets, current liabilities, and inventories for profit maximization and sustainable growth [4-8]. Working capital management significantly contributes to firm value by maintaining a balance between risk and profitability [5,7,9-13]. Depending upon managers' preferences, this balance may have a range of strategies including high risk-high profit (aggressive strategy) or low risk-low profit (conservative strategy) [14].

The literature discusses how investment in working capital influences profit [15-18]. However, the financing of these investments is equally essential for profit maximization. Therefore, studies not only describe the importance of investment but explain how investments should be financed. Financing decisions play an essential role in firm performance. For instance, leverage explains the financing details of a firm and is frequently used in the literature for evaluation of firm performance [15,19-22]. A firm can have multiple sources financing working capital. These sources may be internal, including retained earnings and debt collection, or external, via short- and long-term borrowing [15].

One important external financing decision involves selecting short- or long-term borrowing. When investing in working capital, making good financing decisions are crucial because short-term 
and long-term borrowing have advantages and disadvantages that significantly affect profit and risk. For instance, long-term financing may be a safe strategy as it is free from refinancing uncertainties and interest rate fluctuations. Refinancing uncertainty means the lender, on unsatisfactory firm performance, may refuse to renew the loan on the maturity date. However, short-term financing takes advantage of low interest rates and favorable credit conditions when compared to long-term debt [23]. Short-term financing reduces possible agency problems between creditors, shareholders, and managers of the firm [24]. All these factors support that both short- and long-term debts should be used to finance working capital. Against this background, their best combination should be determined for maximal profit.

Several studies have examined the impact of working capital finance (WCF) on firm performance. Banos et al. [23] analyzed Spanish companies regarding short-term financing with working capital and reported an inverted U-shaped relationship between WCF and profitability. Here, WCF refers to the financing of working capital via short-term borrowing. If a firm finances its working capital by short-term borrowing, a positive WCF-profitability relationship exists, where WCF affects profit positively. However, as short-term borrowing increases, this positive relationship gradually diminishes, and ultimately the firm achieves a break-even point where short-term financing has zero effect on profitability. After this break-even point, a negative WCF-profitability relationship, where WCF affects profit negatively, starts to dominate. This positive and negative combination is cumulatively called an inverted U-shaped relationship. Banos et al. [23] evaluated the influence of financial flexibility on the WCF-profitability relationship and revealed that the WCF-profitability break-even point changes for highly flexible and inflexible firms. Financial flexibility is the capability of a firm to access its financing at low cost [23]. Break-even point shows the proportion of short- and long-term debts in WCF. If its value is 0.60 , WCF carries $60 \%$ short-term and $40 \%$ long-term debts. At the break-even point, WCF has zero effect on profitability. Panda and Nanda [25] analyzed six manufacturing sectors in India and reported changes in the WCF-profitability relationship for each sector. They evaluated the influence of markup (sales to profit margin) on the WCF-profitability relationship and devised a different financing strategy for each manufacturing sector.

From this discussion, small and big companies may behave differently in the WCF-profitability relationship due to different ownership structures, financial flexibility, and tax provisions. Also, other factors such as leverage may influence the WCF-profitability relationship, but have been ignored in previous studies. The current study fills the gap in the literature by evaluating the influence of firm size and leverage on the WCF-profitability relationship. To the best of our knowledge, the moderating effects of these two factors on this relationship have not yet been studied.

Apart from this fundamental contribution, we contribute to the existing literature in numerous ways. First, we observed the changes in the break-even point of the WCF-profitability relationship as the size and leverage level of firms change. Second, we considered a long time period of 18 years with a large number of observations $(12,610)$. Third, this is the first study in China to evaluate the WCF-profitability relationship in the context of firm size and leverage. China is a world-leading economy, with private firms growing remarkably since the introduction of the opening up policy [26]. Finally, we used panel data and conducted analyses using the generalized method of moments (GMM), a modern dynamic technique used to handle numerous data problems including endogeneity and heterogeneity.

The rest of the paper is organized as follows. Section 2 explains the relationship of WCF with firm performance along with the potential influence of firm size and leverage on this relationship. Section 3 discusses the research models and variables used. Section 4 presents the analysis and results. Section 5 summarizes and concludes the study. 


\section{WCF, Profitability, Size, and Leverage}

\subsection{WCF and Firm Profitability}

Modigliani and Miller [27] explained that financing methods are significantly related to profitability in the presence of interest and taxes. Financing methods may be short- or long-term. Both methods have their pros and cons depending upon firm-related characteristics, managers' intentions, and macroeconomic factors. However, short-term financing is generally preferred among shareholders, creditors, and policy makers of the firm [28], enabling lenders to observe firm performance in detail, and thus modify the terms of credit renewals [20].

Firms use different WCF strategies to maximize profit. Aggressive and conservative strategies are commonly practiced [25]. An aggressive strategy prevails when there is a large proportion of short-term debts in WCF. In a conservative strategy, long-term debts have a dominant share. Firms that have an inverted U-shaped relationship in WCF and profitability follow a conservative WCF policy for profit maximization. Conversely, firms that have a U-shaped relationship in WCF and profitability adopt an aggressive strategy to gain maximum profit. The U-shaped relationship is a combination of negative trend, break-even point, and positive trend. Baños-Caballero et al. [23] described an inverted U-shaped relationship in Spanish companies that followed a conservative strategy. Panda and Nanda [25] found inverted U-shaped and U-shaped relationships in various Indian manufacturing sectors that followed conservative and aggressive strategies, respectively.

An increase in short-term debts in WCF gradually increases profit because short-term debts have low interest rates and are free from inflation uncertainties. These two factors become more influential in long-term debts [29]. Short-term borrowing is more flexible to the financial requirements of a firm [29]. Similarly, short-term debts improve firm-lender relationships via repeated renewals, which ultimately reduces interest rates on future debts [30]. Short-term borrowing reduces agency differences among debt holders and shareholders [23]. Similarly, when a lender, via frequent renewals, closely monitors firm performance, it increases investors' confidence. This helps a firm to overcome problems of underinvestment and subsequent underwriting [31]. Lastly, firms that have more attractive investment opportunities use short-term borrowing to promote their positive prospects among external stakeholders [32]. Thus, due to all these factors, short-term debts in WCF have a positive effect on profit. However, this positive WCF-profitability relationship gradually weakens and ultimately approaches a peak level (break-even point) where WCF has zero effect on profitability. After this break-even point, WCF starts affecting profit negatively, establishing an inverted U-shaped relationship between WCF and profitability.

Higher interest charges and refinancing uncertainties are the two main factors that turn an initially positive WCF-profitability relationship into a negative one [29]. When a firm uses more short-term debt, the lender is concerned about timely return. Therefore, the lender not only charges high interest rates on further debt, but is also reluctant to renew this debt on the maturity date. Thus, higher interest charges and renewal uncertainties affect profit adversely, causing a negative WCF-profitability relationship.

From the above discussion, we expected an inverted U-shaped WCF-profitability relationship in Chinese companies and formulated our first hypothesis as follows:

Hypothesis 1. An inverted $U$-shaped relationship and a break-even point in WCF-profitability exist.

\subsection{WCF and Profitability Under the Moderating Role of Firm Size}

The literature demonstrates that large firms have strong market reputations and more assets to invest and therefore enjoy better access to both short- and long-term debt. As a result, these firms have a large portion of WCF in short-term borrowing due to these advantages linked with such debt. Fazzari and Petersen [33] report that small firms have more financial constraints than large firms. Therefore, 
these firms experience unfavorable debt conditions and higher interest charges. Niskanen and Niskanen [34] reported a positive relationship of credit availability with capital market access. Large firms have better access to capital markets, so enjoy better credit availability. Small firms suffer from low lender confidence because they provide informal and asymmetrical financial information [35], and are pursued less by market analysts [36]. Lenders are more confident in large firms as their portfolios are more diversified and hence have a lower risk of bankruptcy [36]. Baños-Caballero et al. [23] and Panda and Nanda [25] agreed that firm size significantly affects the WCF-profitability relationship.

The above discussion reflects a significant moderating role of firm size on the WCF-profitability U-shaped relationship. As small firms suffer from high interest rates on debt, they may demonstrate a reduced positive and extended negative trend in the U-shaped relationship. Also, the break-even point of these firms may appear early and is expected to be lower than the break-even point of the full sample. However, large firms enjoy low interest rates on debt and invest in high-margin projects, so their WCF-profitability U-shaped relationship may prolong positive and reduce negative trends. Their break-even point may appear later and is expected to be higher than the break-even point of the full sample.

Given the above discussion, we formulated the next hypothesis regarding WCF and firm size, as follows:

Hypothesis 2a. The break-even point in the WCF-profitability relationship of small firms is lower than the break-even point of the full sample.

Hypothesis $\mathbf{2 b}$. The break-even point in the WCF-profitability relationship of large firms is higher than the break-even point of the full sample.

\subsection{WCF and Profitability Under the Moderating Role of Leverage}

Panda and Nanda [25] and Baños-Caballero et al. [23] significantly contributed to the understanding of the WCF-profitability relationship under different moderating factors. However, they agreed that their results might vary when the leverage level of a firm changes. Nyeadi and Sare [37] reported that different leverage levels significantly affect profit. Firms with high leverage suffer from the higher cost of short-term debt [22,24]. Such firms mostly use internal sources to repay debt and have to rely on external debt for working capital [4]. Lenders have severe liquidity concerns with high-leverage firms because a significant portion of liquid assets is required to pay back debt charges [37]. High-leverage firms already suffer from heavy debt load and lenders are not willing to provide further loans with normal interest rates, so these firms have to pay premium interest rates on further debt. Also, these firms have a high risk of insolvency and bankruptcy, so may have limited investment opportunities. As a result, these firms are not able to earn as much profit as low-leverage firms. High interest charges further reduce profit. Therefore, we expected leverage to have a strong moderating effect on the WCF-profitability relationship.

Due to low profit, the WCF-profitability relationship of high-leverage firms may reduce the positive and extend the negative trends. Also, their break-even point may appear early and have a lower value compared to the break-even point of the full sample. Conversely, low-leverage firms may have large positive and short negative trends in their WCF-profitability relationship. Their break-even point may appear later and have a higher value compared to the break-even point of the full sample. So, we formulated the next hypothesis as follows:

Hypothesis 3a. The break-even point in the WCF-profitability relationship of high-leverage firms is lower than the break-even point of the full sample.

Hypothesis $\mathbf{3 b}$. The break-even point in the WCF-profitability relationship of low-leverage firms is higher than the break-even point of the full sample. 


\section{Empirical Model and Variables}

We designed Equation (1) to test the relationship between WCF and profitability. This model uses the WCF square variable along with WCF to capture the break-even point. The model is

$$
\begin{aligned}
R O E_{i t}=\alpha & +\beta_{1} W C F_{i t}+\beta_{2} W C F_{i t}^{2}+\beta_{3} \text { Size }_{i t-1} \\
& +\beta_{4} \text { Growth }_{i t-1}+\beta_{5} \text { Leverage }_{i t-1}+\lambda_{t}+\eta_{i} \\
& +\varepsilon_{i t}
\end{aligned}
$$

where $R O E_{i t}$ is a dependent variable, return on equity, which is a proxy for profitability measured by the ratio of net profit to equity [8,9]; $W C F_{i t}$ (working capital finance) is an independent variable measured as (short-term borrowing/(current assets - accounts payable)) $[8,11]$. The control variables repeatedly used in the literature include $S i z e_{i t-1}$ is the log of total assets, Growth $h_{i t-1}$ is the sales growth rate, and Leverage $_{i t-1}$ is the ratio of total debts to total assets $[2,3,6,8,9,24]$. Control variables are used to keep the firm performance free from other possible influences and are lagged by one level to address the problem of endogeneity. $\lambda_{t}$ is the time dummy variable, which changes over time but remains unchanged in the selected time period; $\eta_{i}$ represents unique features of firms, such as geographical position, which remain constant over time and enable us to manage these individual effects; and $\varepsilon_{i t}$ is the error term of the equation. All variables used in the equation are frequently used in the literature, and we also measure these variables through proxies, which are common in the literature.

Firm size is an important variable in this study. Its various proxies, including value of assets, value of sales, market capitalization, $\log$ of assets, $\log$ of sales, and $\log$ of market capitalization, are available in the literature [38]. These proxies have different levels of sensitivity to firm performance [39]. We reviewed the literature and found log of assets to be a more frequently proxy used in the working capital context. Following this, we used the same proxy in our study.

We evaluated changes in the break-even point of the WCF-performance relationship under the moderating effects of size and leverage, so coefficients of WCF and its square were the primary focus. The break-even point in this equation is calculated by $-\beta_{1} / 2 \beta_{2}$. Both the signs and values of these coefficients are important for drawing a concrete conclusion about the WCF-performance relationship and its break-even point.

\subsection{Firm Size}

We evaluated the influence of firm size on the WCF-profitability break-even point. Firm size is calculated as the log of the total assets of the firm. We calculated the median of the firm size variable to divide the sample into small and large firms. Firms with a size value lower than the median were considered small firms, whereas firms with a higher value than the median were considered large firms. We incorporated these effects into Equation (1) by introducing a size dummy variable. This variable has values of 0 and 1 for large and small firms, respectively.

So, Equation (1) was modified to determine the moderating role of firm size on the WCF-profitability relationship:

$$
\begin{aligned}
R O E_{i t}=\alpha & +\beta_{1} W C F_{i t}+\beta_{2} W C F_{i t}^{2}+\gamma_{1} W C F_{i t} \\
& \times \text { Size }_{i t} \text { Dummy }+\gamma_{2} W C F_{i t}^{2} \times \text { Size }_{i t} \text { Dummy } \\
& +\beta_{3} \text { Size }_{i t-1}+\beta_{4} \text { Growth }_{i t-1}+\beta_{5} \text { Leverage }_{i t-1} \\
& +\lambda_{t}+\eta_{i}+\varepsilon_{i t} .
\end{aligned}
$$

This equation has a new break-even point of the WCF-profitability relationship under the moderating effect of firm size, which is calculated as $-\left(\beta_{1}+\gamma_{1}\right) / 2\left(\beta_{2}+\gamma_{2}\right)$. 


\subsection{Leverage}

We also evaluated the influence of leverage on the WCF-profitability relationship. The literature defines leverage as the ratio of total debts to total assets [22]. We calculated the median of the leverage variable to divide firms into high- and low-leverage firms. All firms with a leverage value lower than the median were considered low-leverage firms, whereas firms with higher leverage than the median were considered high-leverage firms. To capture the moderating effect of leverage, we propose a leverage dummy variable. It has values of 0 and 1 for low- and high-leverage firms, respectively.

We therefore modified Equation (1) to capture the moderating effect of leverage on the WCF-profitability relationship:

$$
\begin{aligned}
R O E_{i t}=\alpha & +\beta_{1} W C F_{i t}+\beta_{2} W C F_{i t}^{2}+\varphi_{1} W C F_{i t} \\
& \times \text { Lev }_{i t} \text { Dummy }+\varphi_{2} W C F_{i t}^{2} \times \text { Lev }_{i t} \text { Dummy } \\
& +\beta_{3} \text { Size }_{i t-1}+\beta_{4} \text { Growth }_{i t-1}+\beta_{5} \text { Leverage }_{i t-1} \\
& +\lambda_{t}+\eta_{i}+\varepsilon_{i t .}
\end{aligned}
$$

This equation introduces a new break-even point of the WCF-profitability relationship under the moderating role of leverage, which is calculated as $-\left(\beta_{1}+\varphi_{1}\right) / 2\left(\beta_{2}+\varphi_{2}\right)$.

We used panel data and the GMM estimator to address heteroskedasticity, unobserved heterogeneity, and endogeneity. Endogeneity refers to the correlation of explanatory variables with error terms [40]. There are various techniques used to address endogeneity, including lagged dependent variables, lagged independent variables, control variables, GMM, and fixed effects [41]. Among these, the best is the GMM estimator, which has the highest power to deal with endogeneity [41]. We estimated all models using GMM, a dynamic panel data estimator introduced by Arellano and Bond [42]. GMM transforms data to remove the effects of all sources of endogeneity, including unobserved heterogeneity, simultaneity, and dynamic endogeneity [43]. Transformation occurs when endogenous variables are converted into instrumental variables by taking their lag values. GMM offers multiple lags, and we selected the lags that best address the endogeneity. The Sargan-Hansen test was used to evaluate the effectiveness of these instrumental variables. GMM is also robust to heterogeneity and heteroskedasticity issues with data.

We observed an endogeneity problem in the control variables and therefore took their lags at the first level in all models to remove its potential effects. We used STATA software for analysis.

\subsection{Data and Sample}

The current study is based in China, and we collected 18 years' worth of secondary data (2000-2017). The source of data was the China Securities Market and Accounting Research (CSMAR) database, which has extensive detail of financial statement data of Chinese companies on a quarterly and annual basis [44]. The initial sample size had 18,445 observations of manufacturing firms. We condensed the data in the following ways. First, we eliminated all observations with negative or WCF values more than 1 . Second, we removed observations with negative values of assets, liabilities, inventories, accounts receivable, accounts payable, and short-term borrowing. We also excluded the extreme top and bottom values of each variable used. We obtained a final sample with 12,609 observations.

\section{Analysis and Results}

\subsection{Descriptive Statistics}

Descriptive details of the data, i.e., number of observations, sum, mean, median, standard deviation, minimum, and maximum, for all dependent, independent, and control variables, are listed in Table 1. 
Table 1. Descriptive statistics.

\begin{tabular}{lccccccc}
\hline Variable & $\mathbf{N}$ & Sum & Mean & Median & SD & Min & Max \\
\hline ROE & 12,609 & 3842 & 0.305 & 0.305 & 0.475 & -2.816 & 3.041 \\
WCF & 12,609 & 4631 & 0.367 & 0.367 & 0.252 & 0.00432 & 1.000 \\
WCF $^{2}$ & 12,609 & 2505 & 0.199 & 0.199 & 0.232 & $1.87 \times 10^{-5}$ & 0.999 \\
Size & 12,609 & 119,224 & 9.455 & 9.455 & 0.512 & 7.580 & 11.54 \\
Growth & 12,609 & 28,303 & 2.245 & 2.245 & 3.552 & -0.937 & 55.39 \\
Leverage & 12,609 & 5684 & 0.451 & 0.451 & 0.205 & 0.0188 & 7.872 \\
\hline
\end{tabular}

\subsection{Correlation Matrix and Variance Inflation Factor (VIF)}

A correlation matrix for all variables is provided in Table 2. A correlation analysis measures multicollinearity among independent and control variables. Table 2 shows that return on equity is negatively correlated with our primary independent variable, WCF, and its square. Table 2 reflects that all firm-related control variables, i.e., growth, size, and leverage, are significantly correlated with the dependent variable. All independent and control variables, except WCF-growth, are also significantly correlated with each other, but this correlation is not so strong as to cause multicollinearity problems.

Table 2. Correlation matrix.

\begin{tabular}{lcccccc}
\hline & ROE & WCF & WCF $^{2}$ & Size & Growth & Leverage \\
\hline ROE & 1 & & & & & \\
WCF & $-0.174^{* * *}$ & 1 & & & & \\
WCF2 & $-0.150^{* * *}$ & $0.957^{* * *}$ & 1 & & & \\
Size & $0.215^{* * *}$ & $-0.0489^{* * *}$ & $-0.0453^{* * *}$ & 1 & & \\
Growth & $0.225^{* * *}$ & $0.0135^{* * *}$ & $0.0346^{* * *}$ & $0.103^{* * *}$ & 1 & 1 \\
Leverage & $-0.207^{* * *}$ & $0.393^{* * *}$ & $0.350^{* * *}$ & $0.261^{* * *}$ & $-0.0372^{* * *}$ & 1 \\
\hline
\end{tabular}

Note: ${ }^{*} p<0.05,{ }^{* *} p<0.01,{ }^{* * *} p<0.001$.

We also calculated the variance inflation factor (VIF) for all independent and control variables to confirm the absence of multicollinearity in the sample. A value of VIF higher than five might be an indication that a specific variable suffers multicollinearity [45]. The VIF values for all explanatory variables were far lower than five, confirming that the data are free from multicollinearity. The details of VIF analysis are outlined in Table 3.

Table 3. Variance inflation factor (VIF) statistics.

\begin{tabular}{ccc}
\hline Variable & VIF & 1/VIF \\
\hline WCF & 1.22 & 0.818654 \\
Size & 1.12 & 0.890622 \\
Growth & 1.02 & 0.982236 \\
Leverage & 1.31 & 0.076497 \\
\hline
\end{tabular}

\subsection{WCF and Return on Equity}

Equation (1) explains the WCF-profitability relationship in Chinese firms. The results of Equation (1) are presented in Table 4, which show that the coefficients of all independent and control variables are highly significant. The coefficient of WCF $\left(\beta_{1}\right)$ has a positive value, which indicates a positive WCF-profitability relationship. The coefficient of $\operatorname{WCF}^{2}\left(\beta_{2}\right)$ has a negative value, which shows a negative WCF-profitability relationship. These positive and negative relationships are separated by a break-even point. The positive and negative relationships and the break-even point jointly form an inverted U-shaped WCF-profitability relationship. These results validate our first hypothesis, which stated that an inverted U-shaped WCF-profitability relationship exists. These results are strongly consistent with the results reported by Baños-Caballero et al. [8], and partially support 
Panda and Nanda's [11] findings. This relationship shows that an increase in WCF first establishes a positive WCF-profitability trend. This is due to benefits related to short-term debt, including lower interest charges, favorable credit conditions, mitigation of agency costs, and promotion of positive prospects among external stakeholders. However, a further increase in short-term borrowing weakens the positive trend that ultimately becomes zero. This is the break-even point of this relationship. After the break-even point, the relationship becomes negative. This negative relationship proves the disadvantages of large WCF financing via short-term borrowing, specifically higher interest charges and refinancing uncertainties [29]. Here, the break-even point is 0.80 , calculated as $[-0.83 /(-0.51 \times$ $2)$ ] using the formula $-\beta_{1} / 2 \beta_{2}$. This means firms can support working capital with $80 \%$ short-term and $20 \%$ long-term debt to maximize profit.

Robustness of the First Hypothesis

Following Reference [46], we revised our first equation to determine the robustness of the results obtained in Section 4.3.

$$
\begin{aligned}
R O E_{i t}=\alpha & +\beta_{1} \operatorname{WCF}_{(0,0,80)}+\beta_{2} \operatorname{WCF}_{(0.80, \max )}+\beta_{3} \operatorname{Size}_{i t-1} \\
& +\beta_{4} \operatorname{Growth}_{i t-1}+\beta_{5} \text { Leverage }_{i t-1}+\lambda_{t}+\eta_{i} \\
& +\varepsilon_{i t} .
\end{aligned}
$$

In this equation, we replace $\mathrm{WCF}$ and $\mathrm{WCF}^{2}$ with $\mathrm{WCF}_{(0,0.80)}$ and $\mathrm{WCF}_{(0.80, \max )}$. We split WCF into two categories using the break-even point of Equation (1): WCF with value lower than 0.80 is considered low-WCF and others are high-WCF. $\mathrm{WCF}_{(0,0.80)}$ is equal to $\mathrm{WCF}$ if $\mathrm{WCF}$ has a value from 0 to 0.80 , and 0.80 otherwise. Similarly, $\mathrm{WCF}_{(0.80, \max )}$ has a value of $\mathrm{WCF}$ minus 0.80 if $\mathrm{WCF}$ is greater than 0.80 , and 0 otherwise. Other variables remain unchanged.

The results of Equation (4) indicate that $\mathrm{WCF}_{(0,0.80)}$ and $\mathrm{WCF}_{(0.80, \max )}$ have positive and negative coefficients, respectively. Both coefficients are highly significant and validate the results of Equation (1): An inverted U-shaped WCF-profitability relationship exists. Details of the results of this equation are

\begin{tabular}{|c|c|c|}
\hline Variables & Equation (1) & Equation (4) \\
\hline WCF & $\begin{array}{c}0.829 * * * \\
(0.160)\end{array}$ & \\
\hline $\mathrm{WCF}^{2}$ & $\begin{array}{c}-0.514^{* * *} \\
(0.120)\end{array}$ & \\
\hline $\mathrm{WCF}_{(0,0.80)}$ & & $\begin{array}{c}0.422 * * * \\
(0.079)\end{array}$ \\
\hline $\mathrm{WCF}_{(0.80, \text { max })}$ & & $\begin{array}{c}-0.547^{* * *} \\
(0.233)\end{array}$ \\
\hline Size & $\begin{array}{c}1.197 \text { *** } \\
(0.087)\end{array}$ & $\begin{array}{c}1.208^{* * *} \\
(0.087)\end{array}$ \\
\hline Growth & $\begin{array}{c}0.022 * * * \\
(0.004)\end{array}$ & $\begin{array}{c}0.022 * * * \\
(0.004)\end{array}$ \\
\hline Leverage & $\begin{array}{c}-2.540 * * * \\
(0.231)\end{array}$ & $\begin{array}{c}-2.536 * * * \\
(0.230)\end{array}$ \\
\hline Constant & $\begin{array}{c}-10.506^{* * *} \\
(0.833)\end{array}$ & $\begin{array}{c}-10.562 \text { *** } \\
(0.831)\end{array}$ \\
\hline Observations & 12,609 & 12,609 \\
\hline Wald Test & 538.44 & 540.52 \\
\hline Sargan Test & 232.83 & 235.31 \\
\hline $\mathrm{AR}(1)$ & -7.29 & -7.28 \\
\hline $\operatorname{AR}(2)$ & -2.06 & -2.10 \\
\hline
\end{tabular}
provided in Table 4 .

Table 4. Working capital finance (WCF) and profitability.

Note: Dependent variable is the return on equity; time dummy variables are included in the model but not reported. Wald test evaluates heteroskedasticity. Sargan test was used for overidentifying restrictions that measure the validity of instruments. AR (1) and AR (2) measure the first- and second-order correlation, respectively. Standard errors in parentheses. ${ }^{* * *} p<0.01,{ }^{* *} p<0.05,{ }^{*} p<0.1$. 


\subsection{WCF and ROE Under the Moderating Role of Firm Size}

Equation (2) shows the moderating role of firm size and adds a dummy variable for small and large firms. We assigned 1 and 0 dummy coding for small and large firms, respectively. Results of this equation are highly significant and are presented in Table 5. The results show that an inverted U-shaped WCF-profitability relationship exists for small firms. The break-even point shifts from 0.80 to $0.68[-(-1.002+2.748) /(2 \times(1.103-2.305))]$ and validates Hypothesis $2 \mathrm{a}$, which states that the WCF-profitability break-even point of small firms is lower than the break-even point of the full sample. These results are consistent with the study of Baños-Caballero et al. [23]. The results show that small firms can finance working capital with a combination of $68 \%$ short-term and $32 \%$ long-term debt to maximize profit. The literature explains that small firms have more financial constraints, reduced lender confidence, and informal financial structure, and therefore use short-term debt at higher interest rates. This raises the cost and subsequently lowers the break-even point to 0.68 compared to the break-even point of the full sample.

Table 5. WCF-profitability relationship of small and large firms.

\begin{tabular}{cc}
\hline Variables & Equation (2) \\
\hline WCF & $-1.002^{* * *}$ \\
& $(0.310)$ \\
WCF $^{2}$ & $1.013^{* * *}$ \\
& $(0.239)$ \\
WCF $\times$ Size dummy & $2.748^{* * *}$ \\
& $(0.348)$ \\
$\mathrm{WCF}^{2} \times$ Size dummy & $-2.305^{* * *}$ \\
& $(0.325)$ \\
Size & $1.592^{* * *}$ \\
& $(0.143)$ \\
Growth & $0.022^{* * *}$ \\
& $(0.004)$ \\
Leverage & $-1.902^{* * *}$ \\
& $(0.390)$ \\
Constant & $-14.422^{* * *}$ \\
& $(1.338)$ \\
Observations & 12,609 \\
Wald test & 383.83 \\
Sargan test & 219.50 \\
AR (1) & -7.95 \\
AR $(2)$ & -2.68 \\
\hline
\end{tabular}

Note: Dependent variable is the return on equity. Time dummy variables are included in the model but not reported. Wald test evaluates heteroskedasticity. Sargan test was used for overidentifying restrictions that measure the validity of instruments. AR (1) and AR (2) measure first- and second-order correlation, respectively. Standard errors in parentheses. ${ }^{* *} p<0.01,{ }^{* *} p<0.05,{ }^{*} p<0.1$.

In contrast, large firms show a U-shaped WCF-profitability relationship with negative and positive $\mathrm{WCF}$ and $\mathrm{WCF}^{2}$ coefficients, respectively. The break-even point for these firms moves to $0.50-[(-1.002) /(2 \times 1.013)]$. These results do not support Hypothesis $2 b$. However, these results are consistent with the study of Panda and Nanda [25], reporting the same results in Indian firms. The U-shaped relationship has a negative and positive WCF-profitability relationship separated by a break-even point. This relationship favors an aggressive WCF policy to maximize profit [25]. This relationship supports large companies having better financing options than short-term borrowing. However, some other benefits, such as positive reputation and agency problems, push firms to use costly short-term debt. This creates a negative WCF-profitability relationship. However, as short-term debt increases, the advantages gradually counter the negative trend that ultimately becomes zero at the break-even point. After this point, a positive WCF-profitability relationship starts prevailing. The break-even point of large firms shows a combination of $50 \%$ short-term and long-term debt, and 
profit is minimal at this point. The graph in Figure 1 explains the movement of the break-even point under the moderating role of firm size.

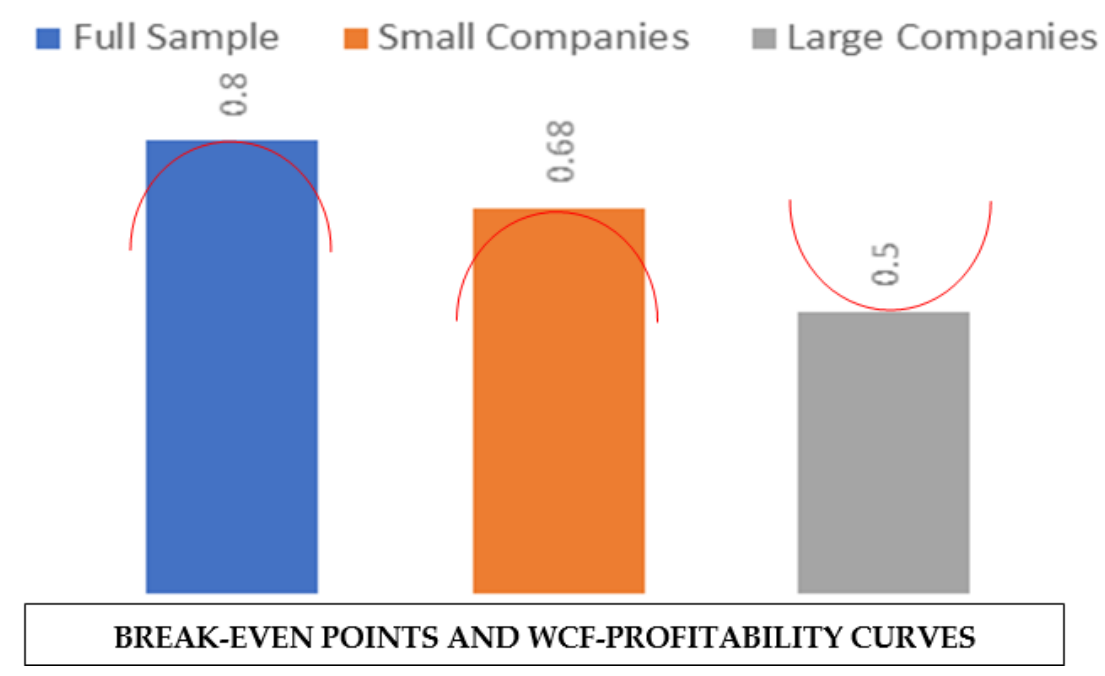

Figure 1. Changes in break-even points for firm size.

The graph shows inverted U-shaped and U-shaped WCF-profitability relationships for small and large firms, respectively. Red lines are showing the "Inverted U-shaped" and "U-shaped" WCF-profitability relationships that contain break-even points. The break-even point for small companies falls to 0.68 compared to the break-even point of the full sample. For large companies, it is further reduced to 0.50 . According to this graph, small companies should adopt a conservative strategy and WCF should not exceed $68 \%$ short-term borrowing. In contrast, large companies should adopt an aggressive financing strategy in which a dominant portion of working capital should be obtained from short-term borrowing.

\subsection{WCF and ROE under the Moderating Role of Leverage}

Equation (3) shows a moderating role of leverage in the WCF-profitability relationship. The results of this equation were also significant for all independent and control variables except growth. Details of the results are presented in Table 6. The results show that high-leverage firms have a U-shaped WCF-profitability relationship. The break-even point for these firms drops to 0.29 [(-3.982 $+5.428) /(2 \times(7.578-10.53))]$, supporting Hypothesis 3a. These results are also consistent with the study of Baños-Caballero et al. [23]. These firms are already under the intense pressure of massive loans, so can access additional loans only at high interest rates. The break-even point falls due to high interest charges and explains that in high-leverage firms, $29 \%$ of WCF should be achieved through short-term borrowing, beyond which a negative WCF-profitability relationship starts prevailing.

In contrast, low-leverage firms show a U-shaped WCF-profitability relationship. WCF and WCF ${ }^{2}$ have highly significant negative and positive trend coefficient values, respectively. These results do not support Hypothesis $3 \mathrm{~b}$ but are consistent with the results reported by Panda and Nanda [25]. The U-shaped relationship means that these firms can generate more profit by following an aggressive WCF policy [25]. This relationship may exist because low-leverage firms have a good reputation among stakeholders and therefore have better alternative financing opportunities than short-term borrowing. Using this costly option adversely affects profit, so a negative WCF-profitability relationship exists. However, these firms have better investment opportunities, which gradually diminish the initial negative trend; subsequently, a positive WCF-profitability relationship prevails. The break-even point for these firms falls to $0.26[-(-3.984) /(2 \times 7.578)]$, which is an indication that these firms have a minimal negative WCF-Profitability relationship, and as short-term borrowing increases beyond $26 \%$ 
of the WCF, this relationship turns positive. Changes in the break-even point under the moderating effect of leverage are depicted by the graph in Figure 2.

Table 6. WCF-profitability relationships for high- and low-leverage firms.

\begin{tabular}{cc}
\hline Variables & Equation (3) \\
\hline $\mathrm{WCF}$ & $-3.984^{* * *}$ \\
& $(1.227)$ \\
$\mathrm{WCF}^{2}$ & $7.578^{* * *}$ \\
& $(2.314)$ \\
$\mathrm{WCF} \times$ Lev dummy & $5.428^{* * *}$ \\
& $(1.653)$ \\
$\mathrm{WCF}^{2} \times$ Lev dummy & $-10.053^{* * *}$ \\
& $(2.774)$ \\
Size & $-0.898^{* *}$ \\
& $(0.385)$ \\
Growth & -0.002 \\
& $(0.008)$ \\
Leverage & $-1.893^{*}$ \\
& $(0.990)$ \\
Constant & $-3.984^{* * *}$ \\
& $(1.227)$ \\
Observations & 12,609 \\
Wald Test & 141.02 \\
Sargan Test & 37.03 \\
AR (1) & -5.00 \\
AR (2) & -2.48 \\
\hline
\end{tabular}

Note: Dependent variable is the return on equity. Time dummy variables are included in the model but not reported. Wald test evaluates heteroskedasticity. Sargan test was used for overidentifying restrictions that measure the validity of instruments. AR (1) and AR (2) measure the first- and second-order correlation, respectively. Standard errors in parentheses. ${ }^{* * *} p<0.01,{ }^{* *} p<0.05,{ }^{*} p<0.1$.

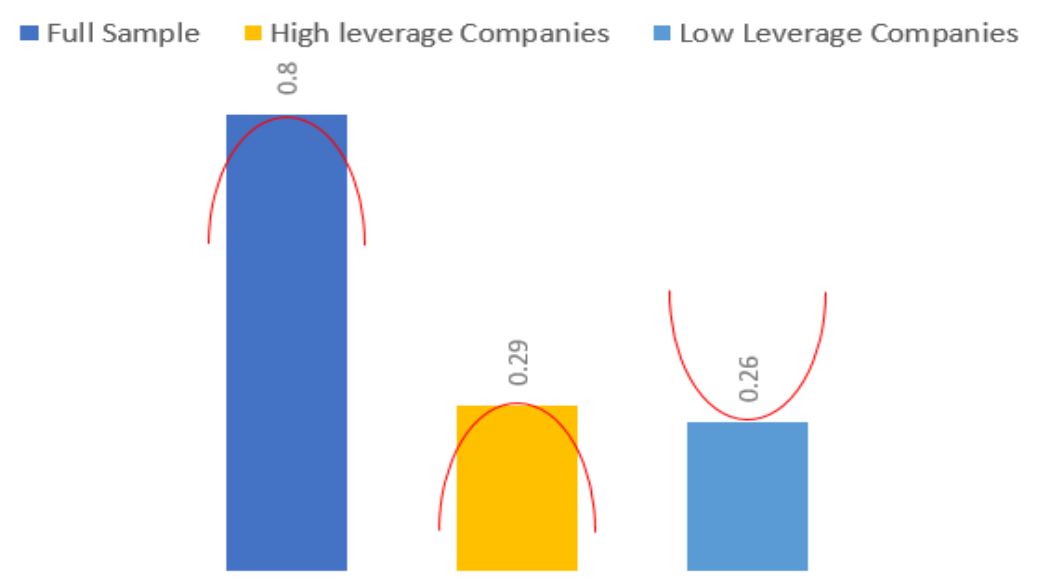

Figure 2. Changes in break-even points for firms with different leverage levels.

The graph shows that the break-even point for both high- and low-leverage firms decreases compared to the full sample. For the full sample, high-leverage firms have the same inverted U-shaped relationship of WCF and profitability as shown in the graph. However, for low-leverage companies, the WCF-profitability curve becomes U-shaped. The results support that high-leverage firms should adopt a conservative strategy and should not exceed short term borrowing up to $29 \%$ of total WCF. However, low-leverage firms may adopt an aggressive financing strategy for profit maximization.

\subsection{Changes in WCF-Profitability Break-Even Point under the Moderating Effects of Firm Size and Leverage}

WCF-profitability break-even points of the full sample and subsamples under the moderating effects of firm size and leverage are depicted in Figure 3. 


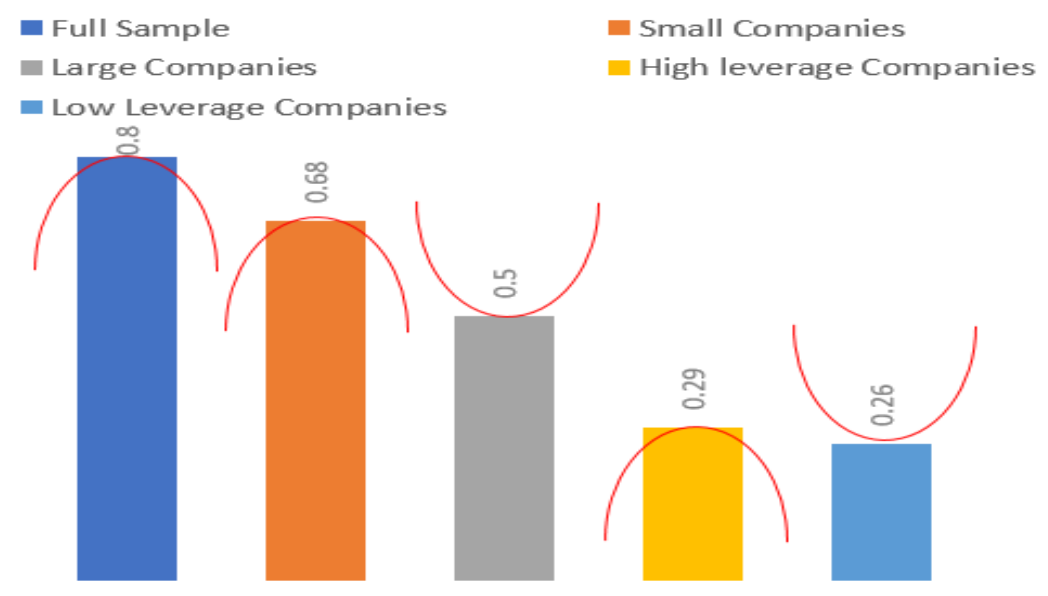

Figure 3. Changes in break-even points for firms of different sizes and leverage levels.

Figure 3 shows that the highest break-even point is for the full sample and the lowest is for low-leverage firms. Small companies have a break-even point of 0.68 , which is the highest among all subgroups. The other two subsamples are large firms and high-leverage firms, with break-even points of 0.50 and 0.29 , respectively. Small companies and high-leverage companies follow the full sample and show an inverted U-shaped WCF-profitability relationship. However, large companies and low-leverage companies have a U-shaped WCF-profitability relationship.

\section{Conclusions}

In this study, we evaluated the WCF-profitability relationship in Chinese companies under the moderating effects of firm size and leverage during a period of 18 years (2000-2017). The literature explored this relationship under financial flexibility and markup. The panel data technique, i.e., GMM, which handles the potential issues of heterogeneity and endogeneity, was used in the main analysis.

The results of the study explain that an inverted U-shaped relationship exists between WCF and firm performance. The results of this study confirm a strong moderating role of firm size and leverage in the WCF-profitability relationship. More specifically, the results revealed that small firms have an inverted U-shaped relationship and their break-even point is lower than the break-even point of the full sample. We observed the same results for high-leverage firms. However, large firms and low-leverage firms show a U-shaped relationship and their break-even points are also lower than the break-even point of the full sample. This means the break-even points of all subgroups are lower than the break-even point of the full sample. The direction of the WCF-profitability relationship shifts from U-shaped to inverted U-shaped only in some subgroups.

The current study provides practical information for managers and policy makers for achieving an optimum WCF-profitability relationship. Specifically, small firms and high-leverage firms should adopt a conservative WCF strategy to maximize profit. In contrast, large firms and low-leverage firms should follow an aggressive strategy for profit maximization. The results could guide managers during modifications of WCF strategy when firms expand or change their leverage level.

We controlled for firm-specific elements in our results and did not consider macroeconomic factors like gross domestic product (GDP) growth, monetary policy, and inflation. These factors may be incorporated in future research to determine their potential influence on the break-even point of the WCF-profitability relationship. We also used data of manufacturing firms only. Non-manufacturing firms' WCF-profitability behavior can also be analyzed in future studies. All the research on the WCF-profitability relationship in the literature has been conducted on unbalanced data. So, another important direction for future research is to confirm these results using balanced panel data, which produce comparatively more authenticated results. 
Author Contributions: Conceptualization, F.M.; methodology, H.D.; software, F.M.; validation, H.D.; formal analysis, F.M.; investigation, R.M.; resources, H.D.; data curation, N.A.; writing, F.M.; review and editing, U.S.; supervision, H.D.; funding acquisition, H.D.

Funding: This project is funded by Heilongjiang Natural Science Foundation (G201107).

Conflicts of Interest: Authors bear no conflict of interest in any part of paper including designing, results interpretations and policy implications. "The funders have no role in the design of the study; in the collection, analyses, or interpretation of data; in the writing of the manuscript, or in the decision to publish the results".

\section{References}

1. Jiang, W.; Lu, M.; Shan, Y.; Zhu, T. Evidence of Avoiding Working Capital Deficits in Australia. Aust. Account. Rev. 2016, 26, 107-118. [CrossRef]

2. Jamalinesari, S.; Soheili, H. The Relationship between the Efficiency of Working Capital Management Companies and Corporate Rule in Tehran Stock Exchange. Procedia Soc. Behav. Sci. 2015, 205, 499-504. [CrossRef]

3. Tran, H.; Abbott, M.; Jin Yap, C. How does working capital management affect the profitability of Vietnamese small- and medium-sized enterprises? J. Small Bus. Enterp. Dev. 2017, 24, 2-11. [CrossRef]

4. Chiou, J.-R.; Cheng, L.; Wu, H.-W. The determinants of working capital management. J. Am. Acad. Bus. 2006, 10, 149-155.

5. Bot,oc, C.; Anton, S.G. Is profitability driven by working capital management? evidence for high-growth firms from emerging Europe. J. Bus. Econ. Manag. 2017, 18, 1135-1155. [CrossRef]

6. Gao, J.; Wang, J. Is Working Capital Information Useful for Financial Analysts? Evidence from China. Emerg. Mark. Financ. Trade 2017, 53, 1135-1151. [CrossRef]

7. Enqvist, J.; Graham, M.; Nikkinen, J. The impact of working capital management on firm profitability in different business cycles: Evidence from Finland. Res. Int. Bus. Financ. 2014, 32, 36-49. [CrossRef]

8. Amelia, M.; Paulo, P.; Gama, M. Working capital management and SMEs profitability: Portuguese evidence. Int. J. Manag. Financ. 2015, 11, 183-191.

9. Tahir, M.; Anuar, M.B.A. The determinants of working capital management and firms performance of textile sector in pakistan. Qual. Quant. 2016, 50, 605-618. [CrossRef]

10. Vahid, T.K.; Elham, G.; Mohsen, A.K.; Mohammadreza, E. Working Capital Management and Corporate Performance: Evidence from Iranian Companies. Procedia Soc. Behav. Sci. 2012, 62, 1313-1318. [CrossRef]

11. Abuzayed, B. Working capital management and firms' performance in emerging markets: The case of Jordan. Int. J. Manag. Financ. 2012, 8, 155-179. [CrossRef]

12. Mun, S.G.; Jang, S.C.S. Working capital, cash holding, and profitability of restaurant firms. Int. J. Hosp. Manag. 2015, 48, 1-11. [CrossRef]

13. Knauer, T.; Wöhrmann, A. Working capital management and firm profitability. J. Manag. Control 2013, 24, 77-87. [CrossRef]

14. Masri, H.; Abdulla, Y. A multiple objective stochastic programming model for working capital management. Technol. Forecast. Soc. Chang. 2018, 131, 141-146. [CrossRef]

15. Akinlo, O.O. Determinants of working capital requirements in selected quoted companies in Nigeria. J. Afr. Bus. 2012, 13, 40-50. [CrossRef]

16. Wasiuzzaman, S. Working capital and firm value in an emerging market. Int. J. Manag. Financ. 2015, 11, 60-79. [CrossRef]

17. Baños-Caballero, S.; García-Teruel, P.J.; Martínez-Solano, P. Working capital management, corporate performance, and financial constraints. J. Bus. Res. 2014, 67, 332-338. [CrossRef]

18. Ben-Nasr, H. State and foreign ownership and the value of working capital management. J. Corp. Financ. 2016, 41, 217-240. [CrossRef]

19. Singh, H.P.; Kumar, S. Working capital requirements of manufacturing SMEs: Evidence from emerging economy. Rev. Int. Bus. Strateg. 2017, 27, 369-385. [CrossRef]

20. Díaz-Díaz, N.L.; García-Teruel, P.J.; Martínez-Solano, P. Debt maturity structure in private firms: Does the family control matter? J. Corp. Financ. 2016, 37, 393-411. [CrossRef]

21. De Almeida, J.R.; Eid, W. Access to finance, working capital management and company value: Evidences from Brazilian companies listed on BM \& FBOVESPA. J. Bus. Res. 2014, 67, 924-934. 
22. Dalci, I.; Ozyapici, H. Working capital management policy in health care: The effect of leverage. Health Policy (N. Y.) 2018, 122, 1266-1272. [CrossRef] [PubMed]

23. Baños-Caballero, S.; GARCÍA-TERUEL, P.J.; MARTÍNEZ-SOLANO, P. Financing of working capital requirement, financial flexibility and SME performance. J. Bus. Econ. Manag. 2016, 17, 1189-1204. [CrossRef]

24. Ozkan, A. Determinants of capital structure and adjustment to long run target: Evidence from UK company panel data. J. Bus. Financ. Account. 2001, 28, 175-198. [CrossRef]

25. Panda, A.K.; Nanda, S. Working capital financing and corporate profitability of Indian manufacturing firms. Manag. Decis. 2018, 56, 441-457. [CrossRef]

26. Ding, S.; Guariglia, A.; Knight, J. Investment and financing constraints in China: Does working capital management make a difference? J. Bank. Financ. 2013, 37, 1490-1507. [CrossRef]

27. Modigliani, F.; Miller, M.H. The Cost of Capital, Corporation Finance and THeory of Investment. Am. Econ. Rev. 1958, 48, 261-297.

28. García-Teruel, P.J.; Martínez-Solano, P. Ownership structure and debt maturity: New evidence from Spain. Rev. Quant. Financ. Account. 2010, 35, 473-491. [CrossRef]

29. Jun, S.-G.; Jen, F.C. Trade-off model of debt maturity structure. Rev. Quant. Financ. Account. 2003, 20, 5-34. [CrossRef]

30. Petersen, M.A.; Rajan, R.G. The benefits of lending relationships: Evidence from small business data. J. Financ. 1994, 49, 3-37. [CrossRef]

31. Barclay, M.J.; Smith, C.W., Jr. The Maturity Structure of Corporate Debt. J. Financ. 1995, 50, $609-631$. [CrossRef]

32. Kale, J.R.; Noe, T.H. Risky debt maturity choice in a sequential game equilibrium. J. Financ. Res. 1990, 13, 155-166. [CrossRef]

33. Fazzari, S.M.; Petersen, B.C. Working capital and fixed investment: new evidence on financing constraints. RAND J. Econ. 1993, 24, 328-342. [CrossRef]

34. Niskanen, J.; Niskanen, M. The determinants of corporate trade credit policies in a bank-dominated financial environment: The case of Finnish small firms. Eur. Financ. Manag. 2006, 12, 81-102. [CrossRef]

35. Jordan, J.; Lowe, J.; Taylor, P. Strategy and financial policy in UK small firms. J. Bus. Financ. Account. 1998, 25, 1-27. [CrossRef]

36. Caballero, B.-S.; Martínez, S.P.; García, T.P. Working capital management in SMEs. Account. Financ. 2010, 50, 511-527. [CrossRef]

37. Nyeadi, J.D.; Sare, Y.A.; Aawaar, G. Determinants of working capital requirement in listed firms: Empirical evidence using a dynamic system GMM. Cogent Econ. Financ. 2018, 6, 1-14. [CrossRef]

38. Aregbeyen, $\mathrm{O}$. The effects of working capital management on the profitability of Nigerian manufacturing firms. J. Bus. Econ. Manag. 2013, 14, 520-534. [CrossRef]

39. Dang, C.; Li, Z.F.; Yang, C. Measuring Firm Size in Empirical Corporate Finance. J. Bank. Financ. 2017, 86, 159-176. [CrossRef]

40. Wintoki, M.B.; Linck, J.S.; Netter, J.M. Endogeneity and the Dynamics of Corporate Governance. J. Financ. Econ. 2012, 105, 581-606. [CrossRef]

41. Li, F. Endogeneity in CEO power: A survey and experiment. Invest. Anal. J. 2016, 45, 149-162. [CrossRef]

42. Arellano, M.; Bond, S. Some tests of specification foSome Tests of Specification for Panel Data: Monte Carlo Evidence and an Application to Employment Equations. Rev. Econ. Stud. 1991, 58, 277-297. [CrossRef]

43. Ullah, S.; Akhtar, P.; Zaefarian, G. Dealing with endogeneity bias: The generalized method of moments (GMM) for panel data. Ind. Mark. Manag. 2018, 71, 69-78. [CrossRef]

44. CSMAR. The CSMAR Economic and Financial Research Database. Available online: http://www.csmar. com/ (accessed on 29 March 2019).

45. Studenmund, A.H.; Cassidy, H.J. Using Econometrics: A Practical Guide; Addison-Wesley Educational Publishers: Boston, MA, USA, 1992.

46. Ghosh, A.; Moon, D. Corporate debt financing and earnings quality. J. Bus. Financ. Account. 2010, 37, 538-559. [CrossRef]

(C) 2019 by the authors. Licensee MDPI, Basel, Switzerland. This article is an open access article distributed under the terms and conditions of the Creative Commons Attribution (CC BY) license (http:/ / creativecommons.org/licenses/by/4.0/). 